\title{
PARASITE COMPLEX OF THE SUGAR BEET MINING MOTH, SCROBIPALPA OCELLATELLA BOYD. \\ (LEPIDOPTERA: GELECHIIDAE) ON SUGAR BEET IN EGYPT
}

\section{SAMIR A. EL-SERWY}

\author{
Plant Protection Research Institute, ARC, Dokki, Giza,
}

(Manuscript received 14 November 2007)

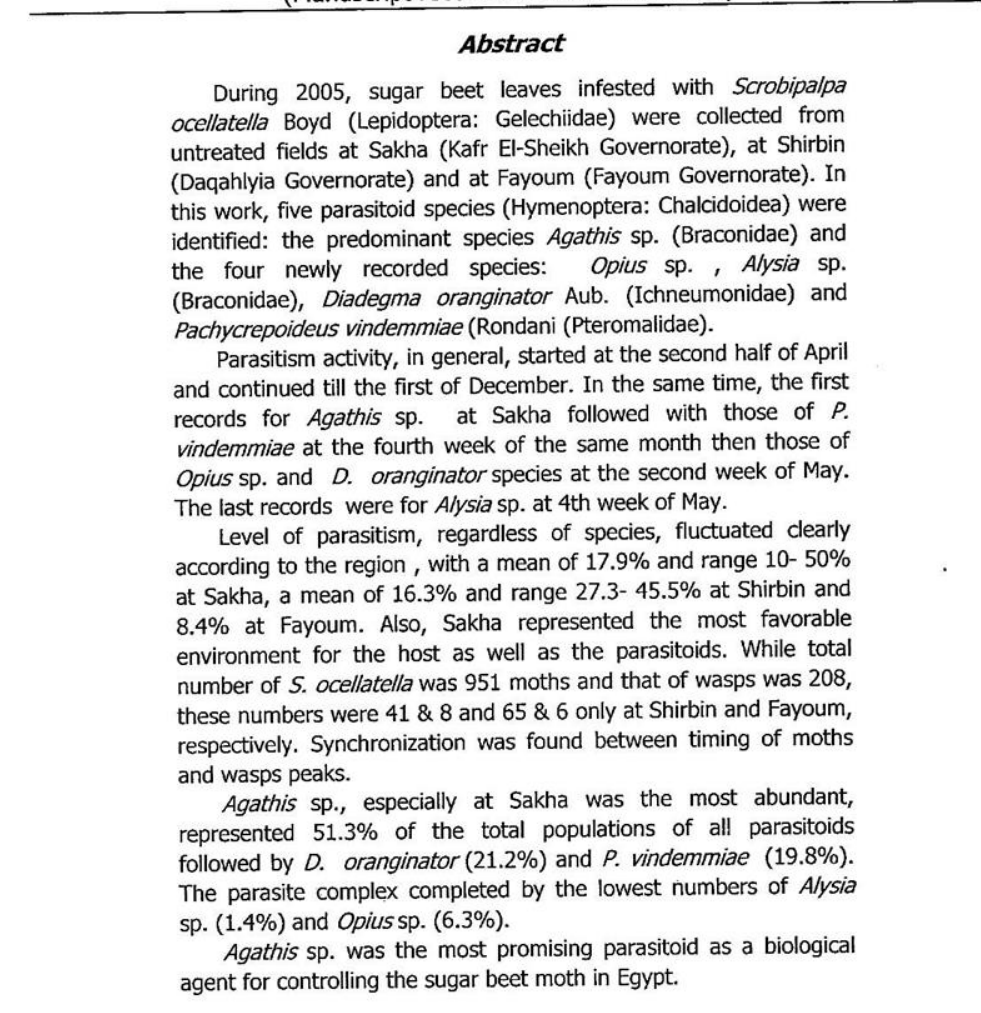

\section{INTRODUCTION}

The sugar beet mining moth, Scrobipalpa ocellatella Boyd., became one of the most important pests attacking sugar beet, Beta vulgaris $\mathrm{L}$., since it was recorded in Egypt by Willcocks (1922). The first two instars larvae attack the succulent heart leaves causing puncture holes, longitudinal slits and short tunnels. These leaves where appeared crinkled, wilt and attached together with a silken web, whereas leaf mid- 
PARASITE COMPLEX OF THE SUGAR BEET MINING MOTH, SCROBIPALPA OCELLATELLA BOYD. (LEPIDOPTERA: GELECHIIDAE) ON SUGAR BEET IN EGYPT

ribs infested by the last instars become soft, black and breakable (El-Sufty et al, 1987). The infestation by this pest resulted a higher weight reduction of roots and sugar content than those caused by the beet fly, Pegomya mixta Vill. or Caccida vittata and reached about 38 and 52\% under severe infestation (Metwally et al, 1987a and Abo-Saied Ahmed, 1987). Several authors contributed to its ecology and biology (Hammad et al, 1968, Metwally et al, 1987b, Awadalla et al, 1991 and El-Agamy et al, 1996). In Egypt, it had seven annual overlapping generations, the shortest and longest generations occurred during June- July and November- early March, respectively, whereas 4-5 generations were found on sugar beet in Serbia ( El-Sufty et al, 1987, Abd El-Ghany, 1994 and ^amprag et al, 1998). The average number of the parasitized larvae was about 44 per female of Agathis sp. (Braconidae), whereas it recorded 7 and $10 \%$ in September and December plantations respectively, reaching a maximum of about $10 \%$ in April and ranged $11-15 \%$ in May and June on late one. However, rates of parasitism ranged 2- $8 \%$ on puparia reared from sugar beet and 4 $6 \%$ on those of chard (Abd El-Ghany, 1994 and El-Agamy et al, 1994a and 1994b). To achieve a sustainable control of this pest, research studies were initiated to determine the parasitoid complex of $S$. ocellatella and role of each species in regulation its population to select the best candidate which will be used as biological control agents in this respect.

\section{MATERIALS AND METHODS}

Sugar beet, fields untreated with pesticides, were selected during 2005 at three Governorates, Kafr El-Sheikh (at Sakha), Daqahlyia (at Shirbin) and Fayoum (at Fayoum). Infested sugar beet leaves by the beet moth, $S$. ocellatella, were detached weekly from April 6 to May 25 at Sakha. Four samples were taken at 10 days interval from May 15 to June 14 at Shirbin, whereas one sample only was taken on April 24 at Fayoum.

On each collection date, the infested leaves were placed into circular plastic containers (each measured $50 \mathrm{~cm}$ diameter $\times 15 \mathrm{~cm}$ height) and provided with a sandy layer at the bottom. The pupae were collected and placed into petri-dishes, 10 $\mathrm{cm}$ in diameter each. The dried leaves were kept in plastic sacs fitted with rubber bands. Daily inspection was made and the emerged moths and parasitoids were collected, identified and recorded. At the end of the emergence season, puparia were dissected and healthy (emerged or failed moths) or parasitized ones (emerged parasitoids from pores or failed emerged parasitoids) werę counted. 


\section{RESULTS AND DISCUSSION}

Data in Table 1 show that, the overall mean of parasitism was $17.4 \%$. There was a marked fluctuation in parasitism rate of $S$. ocellatella at the different localities, $8.4 \%$ at Fayoum, $16.3 \%$ at Shirbin and the highest rate $(17.9 \%)$ was recorded at Sakha. Parasitoids activities started at high (50\%) in early April, declined to $10 \%$ in the next week and again increased gradually to reach $20.3 \%$ in early May. The rate lowered to $14.9 \%$ in the third week of May 2005 at Sakha, but increased to $21.4 \%$ on the 25th in this month. Two rates of 27.3 and $45.5 \%$ were recorded in mid May and June at Shirbin, whereas $8.4 \%$ only was attained in late April at Fayoum.

Five parasitoid species (Hymenoptera: Chalcidoidea) were identified: Agathis sp., Opius sp. (new record), Alysia sp. (new record) (Braconidae), Diadegma oranginator Aub.(new record) (Ichneumonidae) and Pachycrepoideus vindemmiae (Rondani) (new record) (Pteromalidae). Wasps and fore wings of these species are illustrated at Photos 1- 5 (A \& B), respectively.

During the course of this study, the rate of parasitism, distribution and activities of these parasitoids fluctuated greatly. Agathis sp. was the most abundant species and resulted in the highest general rate of $8.9 \%$ comparing with the other parasitoids. This species represented as $12.2 \%$ at Shirbin, $8.9 \%$ at Sakha and $7 \%$ at Fayoum (Table 2). The first emergence of its wasps started in third week of April and continued until the same week of June with a peak of 29 individuals in early June at Sakha, but two individuals were emerged later in early December (Table 3 ). Little emerged wasps of Agathis sp. (1-4) were recorded. during the first half of May only at Fayoum but continued from the third week of May to mid June (1-3 wasps) at Shirbin. The two species, $D$. oranginator and $P$. vindemmiae had low general parasitism rates of 3.7 and $3.4 \%$, respectively with rates of $3.7-4 \%$ at Sakha opposed to $2.0 \%$ for both at Shirbin (Table 2). At Sakha, emergencies of the pteromalid and the ichneumonid began in late April and mid May, respectively and continued until the third week of June with a distinct peak in their populations at early June (Table 3). A number 13 of $P$. vindemmiae wasps was recorded later in early October (Table 3 ). The two parasitoids were represented with one wasp only in late and mid of June at Shirbin, respectively. Opius and Alysia spp. showed the least rate of parasitism, 0.2$1.1 \%$ only, Table (2). Their emergencies began in mid May at Sakha and Fayoum and continued until mid June (Table (3).

These results indicate that, the parasitism was generally higher with a general mean of $17.9 \%$ (range $10.0-50.0 \%$ ) at Sakha when compared to $16.3 \%$ (range $27.3-$ $45.5 \%)$ at Shirbin and a mean of $8.4 \%$ at Fayoum. The highest recorded rates were 
(50.0\%) in early April at Sakha and (27.3 - 45.5\%) in mid May and June at Shirbin coincides with low population of the host. Monthly rate of parasitism at Sakha, increased from $15.9 \%$ in April to $18.5 \%$ in May. The most abundant species was Agathis sp. which represented $51.3 \%$ of the total wasps emerged in this study. It is a widely distributed species resulted in parasitism rates ranged between about 9- $12 \%$ at Shirbin and Sakha and about 7\% at Fayoum . In this respect, different researchers had reported that, rates of parasitism were about 7 and $10 \%$ in September and December plantations, respectively reaching their highest values $11-15 \%$ in May and June on late one, however, the parasitism ranged $2-8 \%$ on puparia reared from sugar beet and 4- 6\% on those from chard (Abd El-Ghany, 1994 and El-Agamy et al, $1994 b$ ) . Each of $D$. oranginator and $P$. vindemmiae represented about $20-21 \%$ of the total beneficials collected and the parasitism was about two times greater at Sakha than at Shirbin. In Egypt, species belongs to genus Diadegma i. e. D. molliplum Himgrn was recorded on Phthorimaea operculella (Zeller) (Gelechiidae) infested potato, Ipomoea batatus Lam., whereas $P$, vindemmiae is a generalist pupal parasitoid resulted in $16 \%$ on puparia of the sugar beet fly, Pegomya mixta Vill. (Hassanein et al, 1985 and El-Serwy, 2007). Opius sp. represented $6.3 \%$ of the total parasitoid population with a rate of $1.1-1.4 \%$ at Sakha and Fayoum. In general, the emergence of the parasitoids began in the third week of April and terminated in early December with a distinct peak in the populations in early June.

With regard to moths, data in Table (4) revealed that, the emergence started firstly in the third week of $S$. ocellatella April ( 2 moths) and continued until late August with a distinct peak (288 moths) in early June at Sakha. Emergencies began in early and mid May and continued relatively in very few numbers until late May and June with a peak at mid May (53 moths)and late June(16 moths) at Fayoum and Shirbin , respectively.

In general, undetected infestation by the sugar beet moth was observed in mid March and continued until mid June with a peak in the population in the third week of May. The first emergence of moths begins in the third week of April and ends in late August with a distinct peak in early June. Several authors reported before that, the three important overlapping generations occurred the period from during early March to late June and the larvae reached a maximum number in June, whereas the moth's peak was during June- August (El-Sufty et al, 1987, Abd El-Gany, 1994 and ElAgamy et al, 1996).

In conclusion, parasite complex and parasitism on S. ocellatella fluctuated highly with region. The five identified parasitoids were recorded at Sakha, while the abundant species Agathis sp. was found with $D$. oranginator and $P$. vindermmiae at 
Shirbin and with Opius sp. at Fayoum with general rates of parasitism about 18, 16 and $8 \%$, respectively. The highest general rates of parasitism (in order of prevalence) were: $8.9 \%$ by Agathis sp., $3.7 \%$ by $D$. oranginator and $3.4 \%$ by $P$. vindemmiae. Parasitism by Agathis sp. was somewhat higher at Shirbin than at Fayoum or Sakha, whereas parasitism by the ichneumond or the pteromalid species was two times greater at Sakha than Shirbin. Synchronization was found between the timing or peaks of emerged parasitoids and moths.

As a result of this study, parasite complex was markedly fluctuated at the different localities. The most common and abundant parasitoid species of the sugar beet mining moth in Egypt is Agathis sp. represented more than $50 \%$ of the total parasitism by all recorded parasitoids. It seems to be the most promising parasitoid to be used as biological control agent against the sugar beet mining moth in Egypt, given that the species Alabagrus stigma (Brulle) [= Agathis stigmatera (Cresson), had been known to be parasitizing Diatraea spp. in the Caribbean islands and South America since the 1920's and introduced from Peru into the United States against Eoreuma loftini(Dayr) (Lepidoptera: Crambidae) infested sugar cane and rice.

\section{ACKNOWLEDGEMENTS}

The author wishes to thank Dr. Michael W. Gates (USDA, Systematic Entomology Laboratory, Agriculture Research Service, USA) for identification of the pteromalid species Pachycrepoideus vindemmiae, and to Dr. Salah Azab (Systematic Department, Plant Protection Research Institute, ARC, Giza, Egypt) for identification of the ichneumonid species Diadegma oranginator Aub. 
PARASITE COMPLEX OF THE SUGAR BEET MINING MOTH, SCROBIPALPA OCELLATELLA BOYD. (LEPIDOPTERA: GELECHIIDAE) ON SUGAR BEET IN EGYPT

Table 1. Collected alive pupae and parasitized puparia of S. ocellatella at Sakha, Shirbin and Fayoum during April- June, 2005.

\begin{tabular}{|c|c|c|c|c|c|c|}
\hline \multirow{2}{*}{ Region } & \multicolumn{2}{|c|}{ Date of collection } & \multirow{2}{*}{ Alive pupae } & \multirow{2}{*}{$\begin{array}{c}\text { Parasitized } \\
\text { pupae }\end{array}$} & \multirow{2}{*}{$\begin{array}{c}\text { Parasitism } \\
\text { (\%) }\end{array}$} & \multirow{2}{*}{$\begin{array}{c}\text { Monthly } \\
\text { parasitism } \\
\text { (\%) }\end{array}$} \\
\hline & Month & Day & & & & \\
\hline \multirow{9}{*}{ Śakha } & \multirow{4}{*}{ April } & 6 & 4 & 2 & 50.0 & \multirow{4}{*}{15.9} \\
\hline & & 13 & 110 & 11 & 10.0 & \\
\hline & & 20 & 21 & 3 & 14.5 & \\
\hline & & 27 & 129 & 26 & 20.2 & \\
\hline & \multirow{4}{*}{ May } & 4 & 62 & 12 & 19.4 & \multirow{4}{*}{18.5} \\
\hline & & 11 & 207 & 42 & 20.3 & \\
\hline & & 18 & 336 & 50 & 14.9 & \\
\hline & & 25 & 290 & 62 & 21.4 & \\
\hline & \multicolumn{2}{|c|}{ Total } & 1159 & 208 & & 17.9 \\
\hline \multirow{6}{*}{ Shirbin } & \multirow{2}{*}{ May } & 15 & 11 & 3 & 27.3 & \multirow{2}{*}{8.1} \\
\hline & & 25 & 26 & 0 & 0.0 & \\
\hline & \multirow{2}{*}{ June } & 4 & 1 & 0 & 0.0 & \multirow{2}{*}{41.7} \\
\hline & & 14 & 11 & 5 & 45.5 & \\
\hline & \multicolumn{2}{|c|}{ Total } & 49 & 8 & & 16.3 \\
\hline & \multicolumn{4}{|c|}{$\%$} & 16.3 & \\
\hline Fayoum & April & 24 & 71 & 6 & 8.4 & 8.4 \\
\hline \multicolumn{3}{|c|}{ Grand Total } & 1279 & .222 & & 17.4 \\
\hline
\end{tabular}




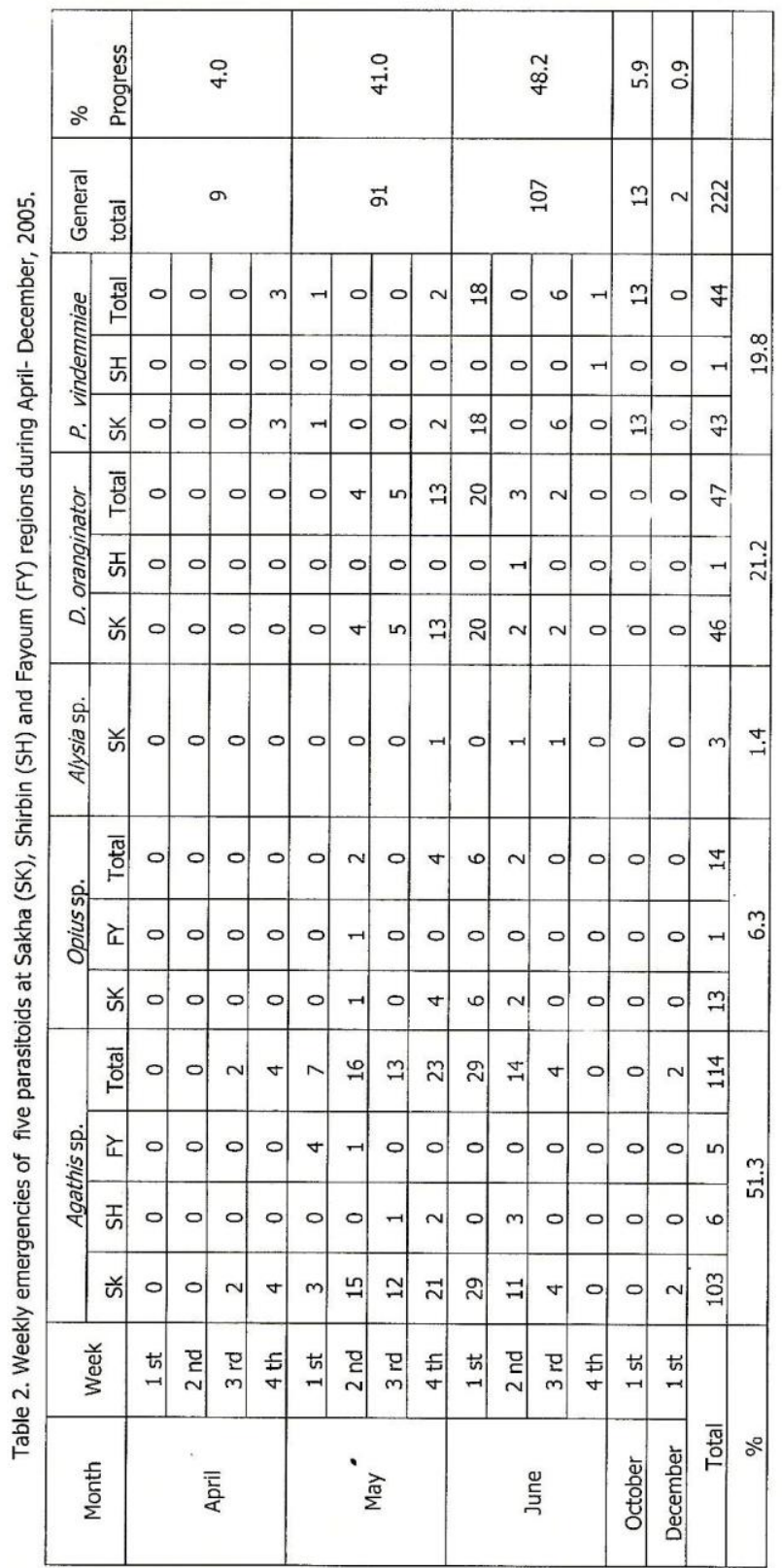



OCELLATELLA BOYD. (LEPIDOPTERA: GELECHIIDAE) ON SUGAR BEET IN EGYPT

Table 3. Percentages of parasitism ${ }^{*}$ in $S$. ocellatella puparia by the different parasitoids at Sakha, Shirbin and Fayoum, 2005.

\begin{tabular}{|c|c|c|c|c|}
\hline \multirow{2}{*}{ Parasitoid species } & \multicolumn{3}{|c|}{ Mean rate of parasitism at: } & \multirow{2}{*}{$\begin{array}{l}\text { General } \\
\text { rate }^{* *} \%\end{array}$} \\
\hline & Sakha & Shirbin & $\begin{array}{c}\text { Fayou } \\
\text { m }\end{array}$ & \\
\hline Agathis sp. & $\begin{array}{c}8.9 \\
(103)\end{array}$ & $\begin{array}{c}12.2 \\
(6)\end{array}$ & $\begin{array}{l}7.0 \\
(5)\end{array}$ & $\begin{array}{c}8.9 \\
(114)\end{array}$ \\
\hline Diadegma oranginator Aub. & $\begin{array}{l}4.0 \\
(46)\end{array}$ & $\begin{array}{l}2.0 \\
(1)\end{array}$ & - & $\begin{array}{c}3.7 \\
(47)\end{array}$ \\
\hline $\begin{array}{l}\text { Pachycrepoideus vindemmiae } \\
\text { (Rondani) }\end{array}$ & $\begin{array}{c}3.7 \\
(43)\end{array}$ & $\begin{array}{l}2.1 \\
(1)\end{array}$ & - & $\begin{array}{c}3.4 \\
(44)\end{array}$ \\
\hline Opius sp. & $\begin{array}{c}1.1 \\
(13)\end{array}$ & - & $\begin{array}{l}1.4 \\
(1)\end{array}$ & $\begin{array}{c}1.1 \\
(14)\end{array}$ \\
\hline Alysia sp. & $\begin{array}{l}0.2 \\
(3)\end{array}$ & - & - & $\begin{array}{l}0.2 \\
(3)\end{array}$ \\
\hline Total & $\begin{array}{c}17.9 \\
(208)\end{array}$ & $\begin{array}{c}16.3 \\
(8)\end{array}$ & $\begin{array}{l}8.4 \\
(6)\end{array}$ & $\begin{array}{l}17.3 \\
(222)\end{array}$ \\
\hline
\end{tabular}

Number between brackets represent total emerged wasps.

*- Related to the total alive pupae in the region.

** - Related to the total alive pupae in all regions (1279).

Table 4. Weekly no. of $S$. ocellatella moths emerged at different regions during AprilAugust, 2005.

\begin{tabular}{|c|c|c|c|c|c|c|}
\hline Month & Week & Sakha & Shirbin & Fayoum & Total & $\begin{array}{c}\% \\
\text { Progress }\end{array}$ \\
\hline \multirow{4}{*}{ April } & $1 \mathrm{st}$ & 0 & 0 & 0 & 0 & \multirow{4}{*}{3.9} \\
\hline & 2 nd & 0 & 0 & 0 & 0 & \\
\hline & $3 \mathrm{rd}$ & 2 & 0 & 0 & 2 & \\
\hline & 4 th & 39 & 0 & 0 & 39 & \\
\hline \multirow{4}{*}{ May } & $1 \mathrm{st}$ & 41 & 0 & 6 & 47 & \multirow{4}{*}{39.5} \\
\hline & $2 \mathrm{nd}$ & 71 & 2 & 53 & 126 & \\
\hline & $3 \mathrm{rd}$ & 103 & 1 & 4 & 108 & \\
\hline & 4 th & 130 & 5 & 2 & 137 & \\
\hline \multirow{4}{*}{ June } & $1 \mathrm{st}$ & 288 & 1 & 0 & 289 & \multirow{4}{*}{56.0} \\
\hline & 2 nd & 218 & 12 & 0 & 230 & \\
\hline & $3 \mathrm{rd}$ & 51 & 4 & 0 & 55 & \\
\hline & 4 th & 2 & 16 & 0 & 18 & \\
\hline \multirow{4}{*}{ July } & $1 \mathrm{st}$ & 0 & 0 & 0 & 0 & \multirow{4}{*}{0.2} \\
\hline & 2 nd & 2 & 0 & 0 & 2 & \\
\hline & $3 \mathrm{rd}$ & 0 & 0 & 0 & 0 & \\
\hline & 4 th & 0 & 0 & 0 & 0 & \\
\hline \multirow{2}{*}{ August } & $1 \mathrm{st}$ & 3 & 0 & 0 & 3 & \multirow{2}{*}{0.4} \\
\hline & 4 th & 1. & 0 & 0 & 1 & \\
\hline \multicolumn{2}{|c|}{ Total } & 951 & 41 & 65 & 1057 & \\
\hline
\end{tabular}



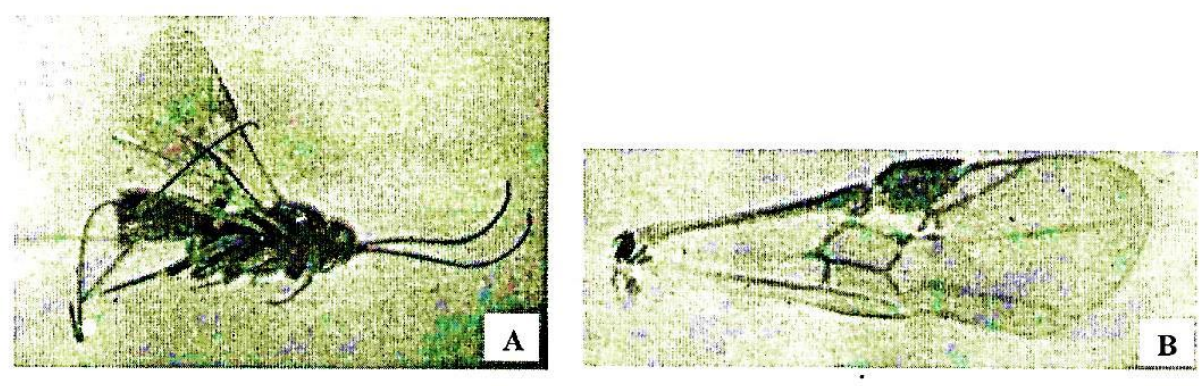

Photo 1-Agathis sp. (Braconidae: Agathidinae) ( A ) and fore wing ( B ).
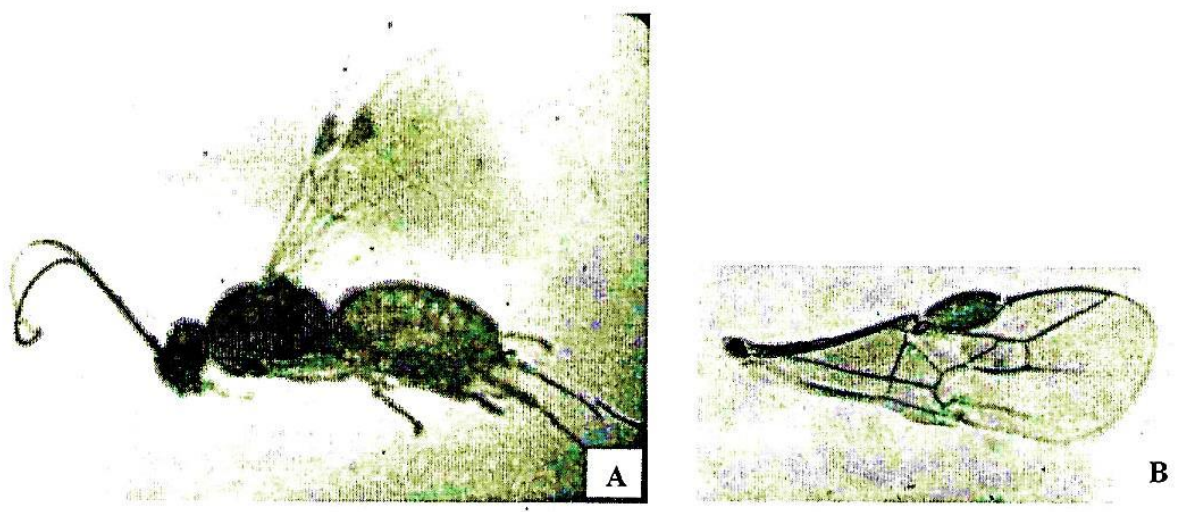

Photo 2: Opius sp. (Braconidae: Opiinae) (A) and fore wing (B).
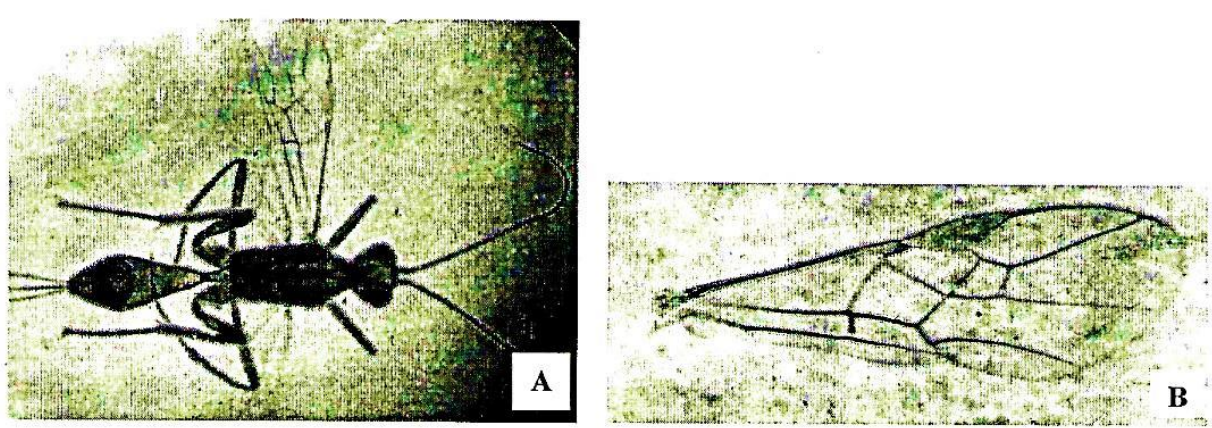

Photo 3: Alvsia sp. (Braconidae: Alysiinae) (A) and fore wing (B). 

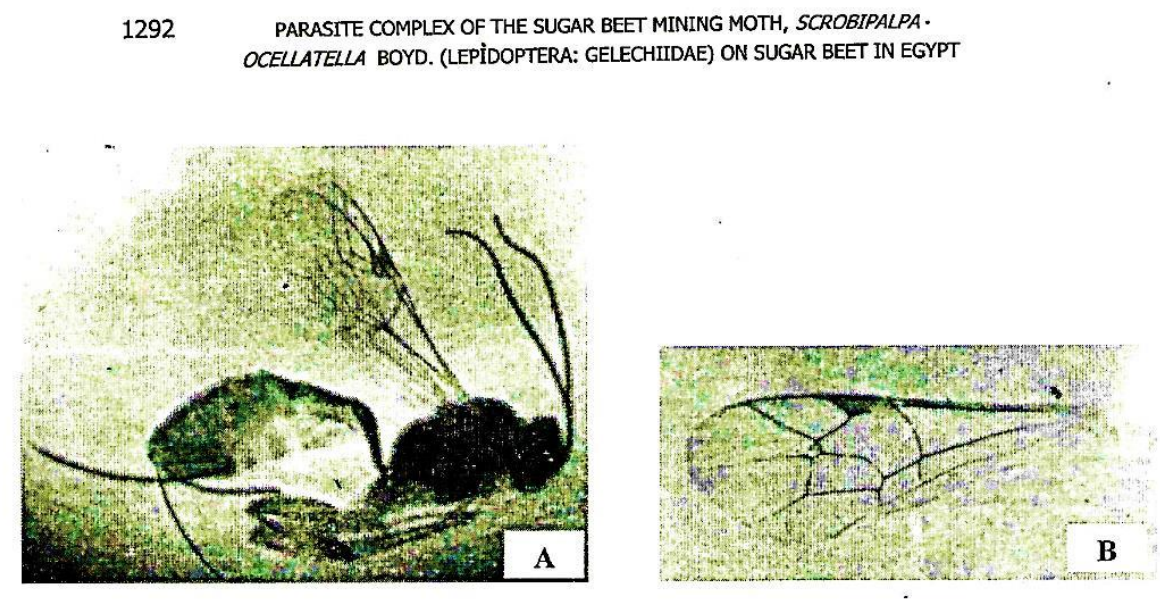

Photo 4. Diadegma oranginator Aub. (Ichneumonidae) (A) and fore wing (B).
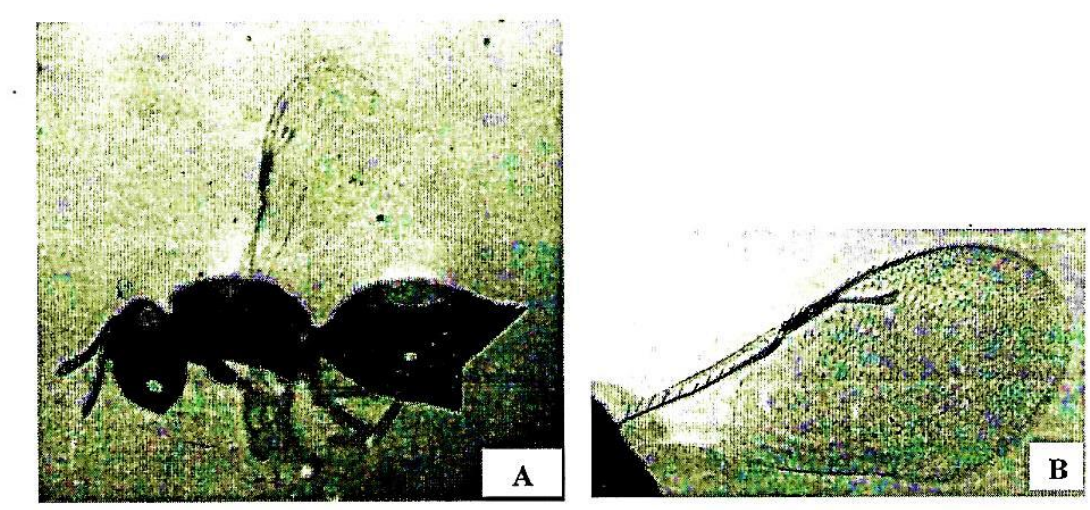

Photo 5: Pachycrepoideus vindemmiae (Rondani) (Pteromalidae) (A) and fore wing (B). 


\section{REFERENCES}

1- Abd El-Ghany, M. A. 1994. Studies on the beet moth, Scrobipalpa ocellatella Boyd, at Kafr El-Sheikh region. M. Sc. Thesis, Fac. of Agric., Tanta Univ., :116 pp.

2- Abo-Saied Ahmed, A. M. B. 1987. Studies on the insects of sugar beet in Kafr ElSheikh Governorate. Ph. D. Thesis, Fac. of Agric., Tanta Univ., : 152 pp.

3- Amprag, D., K. Tatjana, S. Radosav and ]. Petar. 1998. Monitoring of pest population dynamics- A Cornerstone of integrated pest management in field crops. Proc. Vrnja Ka Banja: 7- 12.

4- Awadalla, S. S., M. E. Ragab and H. M. Fathy. 1991. Interaction between injurious and predatory insects inhabiting sugar beet plants. Egypt. J. Biol. P. Cont. 1 (2): 25- 32.

5- El-Agamy, F. M., S. M. I. Metwally, R. El-Sufty and A. Youssef. 1994a. Preliminary biological studies of sugar- beet beetle, Cassida vittata de Villers, sugar- beet fly, Pegomyia mixta vulluve and sugar- beet moth, Scrobipalpa-ocellatella Boyd . J. Agric. Res. Tanta Univ., 20(1): 530- 538.

6- El-Agamy, F, M., S. M. I. Metwally, R. El-Sufty and A. Youssef. 1994b. Incidence of parasitism in the sugar beet fly, Pegomyia mixta Villenuve and the sugar beet moth, Scrobipalpa ocellatella Boyd in Kafr El-Sheikh Governorate. Egypt. J. Biol. Pest Control 4 (2): 27- 32.

7- El-Agamy, F. M., S. M. I. Metwally, R. El-Sufty and A. Youssef. 1996 . The relationship between population fluctuations of some important insect pests of sugar- beet and their insect predators at Kafr El-Sheikh region.. J. Agric. Res. Tanta Univ., 22 (1): 69- 76.

8- El-Serwy, S. A. 2007. Pachycrepoideus vindemmiae (Rondani), a new record parasitoid (Hymenoptera, Pteromalidae) on pupae of the beet fly Pegomya mixta Villeneuve (Diptera: Anthomyiidae), and the beet moth, Scrobipalpa ocellatella (Boyd) (Lepidoptera: Gelechiidae). Egypt. J. Agric. Res., : (In Press).

9- El-Sufty, R., S. M. I. Metwally and A. Youssef. 1987. Studies on the bionomics of the sugar- beet mining moth, Scrobipalpa ocellatella (Boyd) (Lepidoptera: Gelechiidae) at Kafr El-Sheikh, Egypt. J. Agric. Res. Tanta Univ., 13 (4): 11411152. 
10- Hammad. S. M., K. E. Youssef and M. A. Assem. 1968. The biology of the sugarbeet mining moth, Scrobipalpa ocellatella (Boyd) (Lepidoptera: Gelechiidae). Bull. Soc. ent. Egypt. LII: 49- 51.

11- Hassanein, F. A., A. H. El-Heneidy, M. S. T. Abbas and A. R. Hamed. 1985. Survey of the parasitoids of main lepidopterous pests in vegetable crop fields in Egypt. Bull. Soc. Ent. Egypte,65: 259- 265.

12- Meagher R. L. , J.W. Smith, H.W. Browning and R. R.. Saldana. 1998. Sugarcane stem borers and their parasites in southern Texas. Env. Ent. 27: 759-766.

13- Metwally, S. M. I., R. El-Sufty, N. El-Dakhakhny and A. Bassiouny, 1987a. Effect of infestations with certain insect pests on some sugar- beet properties. J. Agric. Res. Tanta Univ., 13 (4): 1119- 1128.

14- Metwally, S. M. I., R. El-Sufty, N. El-Dakhakhny and A. Bassiouny. 1987b. Survey and seasonal abundance of insects associated with sugar- beet at Kafr El-Sheikh, Egypt. J. Agric. Res. Tanta Univ., 13 (4): 1129-1140.

15- Willcocks, F. C. 1922. A survey of the more important and economic insects and mites of Egypt. Bull. Sult. Agric. Tech. Sec. No. 1, Cairo: 482 pp. 


\section{تعذد طفيليات صاتعة أنفات أوراق بنجر السكر}

\section{Scrobipalpa ocellatella Boyd.}

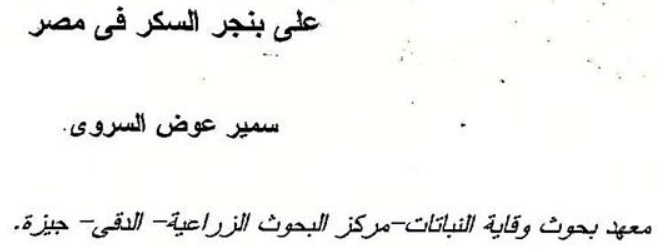

